\title{
THE ROLE OF ONLINE ADVERTISING IN SHAPING THE POLITICAL CULTURE OF YOUNG PEOPLE
}

\author{
Yulya Vovk ${ }^{1}$ Larysa Klymanska ${ }^{2}$ \\ Lviv Polytechnic National University, Lviv, Ukraine \\ ${ }^{1}$ Student, Department of Sociology and Social Work \\ ${ }^{2}$ Doctor of Political Science, Professor, Department of Sociology and Social Work
}

Background: Every year, social networks and other online platforms replace the traditional media (newspapers, television, radio). That is why the Internet becomes a platform for political advertising. Political online advertising has the ability to shape and to change people's worldview and behavior. After all, advertising is a powerful means of influencing and manipulating of a person. As young people are a category of people who, more than representatives of other age groups, spend time online, perceive the Internet as the main source of information, this topic is relevant for research and analysis.

Purpose: to analyze the role of online advertising in the formation of youth political culture

Methods: Theoretical and statistical methods of research were used to identify all kinds of young people's activity on social networks in discussing political topics, as well as to analyze research that has already been done on this topic. A quantitative analysis of the online political audience was conducted, and the content analysis used to determine the amount of political advertising that happens to young people on the Internet during the month (April 2020).

Results: Political advertising can be seen as a system of political communications through which consciousness and the behavior of people is changed for the purpose of the political power that creates this product. We are seeing intense interest in political events, but very low levels of real political activity of young people.

Conclusion: The results indicate that young people are more active in discussing political events in social media than showing real political activity. It is precisely political advertising that appeals to emotions, uses the representations of young people, and shapes the direction of certain political behavior to influence the political culture of young people.

Keywords: youth, political culture, political online advertising, political activity, social internet networks.

3 кожним роком соціальні мережі та інші інтернет платформи заміняють традиційні засоби масової інформації (газети, телебачення, радіо). Загалом, соціальною мережею Facebook в Україні користується 31\% населення, a Instagram - 26\% (У 2019 році Facebook та Instagram).

Можна дійти висновку, що погляди, культура і бачення молодих людей формуються здебільшого на базі інформації з соціальних мереж. Великий вплив на формування політичної культури молоді має політична реклама. Недаремно сучасні науковці розглядають рекламу як визначену психологічну технологію, орієнтовану на маніпулювання мотиваційно-потребовою і свідомою сферами особистості для досягнення соціально-політичних, економічних і інших переваг та стверджують, що реклама - могутній засіб впливу і маніпуляції людиною, i як феномен здатна формувати і змінювати світогляд і поведінку людей (Довгань, 1997).

Оскільки молодь це категорія людей, які більше, ніж інші вікові групи, проводять час онлайн, сприймають інтернет як основне джерело інформації, саме тому ця тема $є$ актуальною для дослідження і аналізу. I безпосередньо цю тему можна розглядати в одному із напрямків конференції «Соціологія - соціальна робота та соціальне забезпечення - регулювання соціальних проблем» і трактувати молодь як одного з суб'єктів цього процесу.

Наше дослідження має на меті проаналізувати роль інтернет реклами у процесі формування політичної культури молоді.

Теоретичні та статистичні методи дослідження використовувались для визначення всіх видів активності молодих людей у соціальних мережах в обговоренні політичних тем для 
3'ясування відсоткового відношення видів активності, щодо обговорення політичних тем користувачами політичних груп на просторах соціальних мереж, а також для аналізу досліджень, проведених різними організаціями пов'язаних 3 нашою темою. Проведено кількісний аналіз аудиторії політичних каналів онлайн, методом контент- аналізу визначено кількість політичної реклами, що трапляється молодим людям в інтернеті протягом останнього місяця (квітень 2020).

Дослідники одноголосно вважають, що політична інтернет реклама відіграє значну роль у формуванні політичної культури молоді, і зазначають, що спостерігається доволі суперечлива ситуація: з одного боку, більшість молодих людей не реагує на політичну рекламу як таку і не бере участі у політичних заходах чи не є членами політичних і громадських організацій, 3 іншого боку, та ж сама більшість є доволі активною в обговоренні політичних тем на просторах соціальних мереж (Вахула, 2012). Тобто, можемо спостерігати інтенсивний інтерес до політичних подій, але дуже низькі показники реальної політичної активності молодих людей. Можливою причиною такої ситуації є недосконалість процесу політичної соціалізації в сучасних умовах, коли спостерігається відірваність молодого покоління від політичного життя країни, брак механізмів реалізації політичної активності для молодих людей. Молодь зневірена у власних силах, не відчуває достатніх можливостей для впливу на перебіг політичних подій, але все-таки усвідомлює, що ії життя напряму залежить від політики, а тому цікавиться нею в постійному режимі онлайн.

Про те, що молодь цікавиться політикою, свідчить інформація, що більшу частину рейтингу Володимира Зеленського перед президентськими виборами в Україні 2019 року становили молоді виборці. За даними січневого соціологічного опитування групи "Рейтинг", за нього готові були проголосувати 31\% осіб віком від 18 до 29 років (Коваль, 2019). I можна припустити, що це поява нового обличчя на політичній арені, і зокрема постійне висвітлення політичної програми В.Зеленського в інтернет рекламі в такий спосіб вплинула на зацікавленість молоді, або ж це було небажання розбиратись у політичних програмах інших кандидатів.

Свою мотивацію щодо голосування за Володимира Зеленського молоді люди пояснюють так: « Зеленський хоче змінити систему, а ми любимо йти проти системи».

Аналіз результатів дослідження «Передвиборча агітація у Facebook та Instagram 2019» Всеукраїнської громадської організації "Громадянська мережа «ОПОРА» засвідчив, що:

- під час активної стадії виборчої кампанії з 24.05.2019 по 15.07.2019 в соціальній мережі Facebook було опубліковано 40427 рекламних дописів політичного характеру;

- у Facebook політична партія «Голос» розмістила у соцмережі 470 рекламних записів. Партія найчастіше спрямовувала свою рекламу на жителів м. Львів - майже $11 \%$ від усіх переглядів, та на жителів м. Київ;

- у віковій структурі ще однієї партії, яка була серед переможців виборчих перегонів 2019 року, партії «Голос» - аудиторія була наймолодшою, окрім цього це єдина партія агітаційні матеріали якої з'являлись у громадян молодше вісімнадцяти років;

- політична партія «Опозиційна платформа - За Життя» розмістила у Facebook 2350 рекламних публікацій на суму більше 47 тисяч доларів. Цільовою аудиторією рекламних дописів стали виборці, старше 35 років, що проживають у південних та східних областях України;

- поряд з активним використанням соціальних мереж політичними партіями та кандидатами в агітаційних цілях також збільшилась кількість рекламних публікацій з елементами «чорного піару», проте здебільшого ці матеріали поширювалися проти кандидатів в одномандатних округах. А саме чорний піар, найбільше зацікавлює молодь і залучає до обговорення іiі в інтернеті, особливо, якщо є можливість анонімно висловлювати свою думку;

-якщо на початку 2018 року лише 23\% молодих українців мали твердий намір взяти участь у голосуванні, а ще 38\% заявляли, що найімовірніше проголосують, то в січні 2019 це вже були 39\% і 36\% відповідно. Тобто все більше молодих людей були готові таки дійти до виборчих дільниць; 
- на інформаційній платформі Фейсбук під час передвиборчої кампанії 2019 року рекламу партії «Слуга народу» переглянуло 15\% жінок віком 24-35 років і $11 \%$ чоловіків цього ж віку , і також 6\% жінок і 4 \% чоловіків віком 18-24 роки. Було створено 240 політичних публікацій у єдиній спільноті фейсбук «Слуга народу» (Лорян, 2019).

Ми розуміємо, що останнім часом громадянська участь молоді проявляється перш за все, в новому інформаційному середовищі - інтернет-просторі. Майданчиками для комунікації молоді в інтернет середовищі, місцем пошуку однодумців, обміну поглядами, реалізації свого права на участь в громадсько-політичному житті держави стали соціальні мережі.

Прямим виявом ролі політичної інтернет реклами у процесі формування політичної культури молоді $\epsilon$ поява нового виду громадського діяча - лідера соціальної спільноти. Потенційно ним може стати буквально кожен користувач інтернету, який має власні суспільно корисні ідеї, володіє достовірною інформацією та вміє логічно викладати свої думки, готовий брати активну участь в їх обговоренні та реалізації задумів.

Щодо позитивних аспектів ролі політичної реклами у процесі формування політичної культури молоді до них можна віднести наступні: а) соціальні інтернет-мережі дають змогу молодим людям ефективно реалізувати свої права; б) вони здатні формувати громадянську позицію з тих чи інших суспільно значущих питань; в) соціальні інтернет-мережі дозволяють оперативно реагувати на зміну політико-правових умов; г) самі собою не потребують фінансової підтримки (Білик, 2004).

Отже, політична реклама може розглядатися як система політичних комунікацій, за допомогою якої змінюється свідомість, поведінка людей, з метою, яку ставить перед собою та політична сила, що створює цей продукт. Ефективна зміна установок, цілей, світогляду, симпатій, інтересів молодих людей може відбуватися тільки за умов пробудження їхніх емоцій та почуттів, на чому власне і робить акцент політична реклама.

Отримані результати свідчать, що молодь є більш активна в обговоренні політичних явищ та подій у соціальних мережах, ніж проявляє реальну політичну активність. На політичну культуру молоді неабиякий вплив справляє саме політична реклама, яка звертається до емоцій, використовує уявлення молодих людей, і формує настанову на певну політичну поведінку.

\section{References}

Bilyk M. (2004) Peculiarities of Formation of Political Culture of Modern Youth // Social Psychology. - No. 4 (6);

Vakhula B. Ya. (2012) Social internet networks, their functions and role in the formation of civil society // Visnyk of Lviv National University. - No. 6;

Dovgan AO (1997) Political Advertising: A Dictionary of Terms and Concepts. - Ternopil, 1997;

Facebook and Instagram 2019 Campaigning Research by All-Ukrainian Non-Governmental Organization "OPORA" Civic Network; Retrieved from: https://bit.ua/2019/09/social_media/;

Koval R. (2019) For whom will the youth vote in the Ukrainian elections and why. Retrieved from URL: https://www.pravda.com/articles/2019/02/20/7207112/;

Loryan R.(2019) Political agitation on the social network Facebook. Retrieved from URL: // https: //www.oporaua.org/article/vybory/parlamentski-vybory/parlamentski-vybory-2019/FB_ad;

In 2019, Facebook and Instagram in Ukraine removed 1 million accounts and received as many new users - research. Retrieved from: https://plusone.com/blog/u_2019_rotsi_facebook_ta_instagram_v_ukrayini_vydalyly_1_mln akauntiv_i_otrymaly_stilky_zh_novyh_korystuvachiv_doslidzhennya/.

\section{Список використаних джерел}

Білик М.(2004) Особливості формування політичної культури сучасної молоді // Соціальна психологія. - № 4 (6).

Вахула Б. Я. (2012) Соціальні інтернет-мережі, їхні функції та роль у формуванні громадянського суспільства // Вісник Львівського університету. - Вип. 6.

Довгань А. О.(1997) Політична реклама: Словник термінів і понять. - Тернопіль, 1997. 
Дослідження «Передвиборча агітація у Facebook та Instagram 2019» Всеукраїнської громадської організації "Громадянська мережа «ОПОРА»; Отримано 3 URL: https://bit.ua/2019/09/social_media/

Коваль Р.(2019) За кого голосуватиме молодь на українських виборах і чому. Отримано 3 URL: https://www.pravda.com.ua/articles/2019/02/20/7207112/

Лорян Р. (2019) Політична агітація у соціальній мережі Facebook. Отримано 3 URL://https://www.oporaua.org/article/vybory/parlamentski-vybory/parlamentski-vybory2019/FB_ad

У 2019 році Facebook та Instagram в Україні видалили 1 млн акаунтів і отримали стільки ж нових користувачів - дослідження. Отримано 3 URL: https://plusone.com.ua/blog/u_2019_rotsi_facebook_ta_instagram_v_ukrayini_vydalyly_1_m In_akauntiv_i_otrymaly_stilky_zh_novyh_korystuvachiv_doslidzhennya/ 